\title{
REPRESENTASI PEJABAT PEMERINTAH TERHADAP KEBIJAKAN LOCKDOWN PADA TAYANGAN ILC TV ONE
}

Representation of Government Officials Regarding the Lockdown Policy on The ILC TV One Show

\author{
Yustitiayu Novelly, Siska Andes Madya, dan Ngusman Abdul Manaf \\ Universitas Negeri Padang \\ ynovelly@gmail.com
}

Naskah Diterima Tanggal 3 Februari 2020_-Direvisi Akhir Tanggal 21 Februari 2021—Disetujui Tanggal 15 Juni 2021 doi: https://doi.org/10.26499/rnh.v10i1.3488

\begin{abstract}
Abstrak
Tujuan penelitian ini adalah untuk mengungkapkan bagaimana representasi pejabat pemerintah tentang pro dan kontra lockdown oleh pihak yang pro dengan kebijakan pejabat pemerintah; dan bagaimana representasi pejabat pemerintah tentang prokontra lockdown oleh pihak yang kontra dengan kebijakan pejabat pemerintah dalam menyampaikan ideologinya dalam tuturan di talk show ILC TV ONE dengan tema Corona: Pro dan Kontra Lockdown. Jenis penelitian ini adalah penelitian kualitatif dengan metode deskriptif. Teknik analisis data yang digunakan dalam penelitian ini adalah analisis wacana kritis model Norman Fairclough yang meliputi teks, discourse practice, dan sociocultural practice. Pendekatan penelitian ini berupa pendekatan kualitatif prespektif AWK Norman Fairclough. Hasil penelitian ini menunjukkan bahwa, bahwa tidak satu suara apakah pro atau kontra lockdown. Karena banyak pertimbangan dan bayangan-bayangan jika lockdown dilakukan apa dampaknya dan jika tidak dilakukan apapula dampaknya. Ada 3 temuan representasi dari tuturan pejabat pemerintah atas kebijakan lockdown, yaitu (1) Pejabat pemerintah dalam tuturannya tidak mempunyai kendali yang kuat untuk membuat keputusan, pejabat pemerintah daerah masih bermain aman dan menjaga kehormatan kepada pemerintah diatasnya. (2) Pejabat pemerintah pusat yaitu diwakili oleh jubir Presiden hanya bisa memberikan penjelasan pendidikan mengenai apa itu sosial distancing dan apa itu lockdown serta kebijakan yang dilakukan; dan (3) Pejabat pemerintah wakil rakyat dan pakar mengkritisi kebijakan yang diambil pemerintah belum maksimal dan tidak tegas.
\end{abstract}

Kata-kata kunci: representasi, pejabat pemerintah, kebijakan lockdown, analisis wacana

\begin{abstract}
The purpose of this study is to see how the representation of government officials about the pros and cons of lockdown by those who are pro with the policy of government officials; and how the representation of government officials about the lockdown counter by those who are counter to the policy of government officials in conveying their ideology in a speech on the ILC TV ONE talk show with the theme Corona: Pro and Counter Lockdown. This type of research is qualitative research with descriptive methods. The data in this study were in the form of speeches from each of the speakers, namely government officials and experts. The subjects in this study were government officials and experts who were the speakers at the ILC TV ONE program. The approach of this research is AWK Norman Fairclough's qualitative approach. The results of this study indicate that, that there is no one vote whether the pros or cons lockdown. Because there are a lot of considerations and shadows if the lockdown is done what the impact is and if nothing is done. There are 3 findings of representation from government officials' statements on the lockdown policy, namely (1) Government officials in their speeches do not have strong control to make decisions, local government officials still play it safe and
\end{abstract}


maintain respect for the government above it. (2) Central government officials, which are represented by the President's spokesman, can only provide an educational explanation on what is social distancing and what is lockdown and the policies that are carried out; and (3) Representative government officials and experts criticizing the policies taken by the government have not been maximized and are not firm.

Keywords: representative, government official, lickdown policy, analysis

How to Cite: Novelly, Yustitiayu, Siska Andes Madya, dan Ngusman Abdul Manaf. (2021). Representasi Pejabat Pemerintah terhadap Kebijakan Lockdown pada Tayangan ILC TV One. Ranah: Jurnal Kajian Bahasa. 10(1).59-72. doi: https://doi.org/10.26499/rnh.v10i1.3488

\section{PENDAHULUAN}

Virus Corona bisa dikatakan menjadi simalakama bagi setiap bangsa. Setiap kebijakan yang diambil oleh pemerintah memiliki dampak positif dan negatifnya, dengan kata lain seperti tidak ada benarnya. Tidak ada bedanya dengan negara lain, Indonesia juga mengalami hal yang sama. Pada awal Maret Presiden Jokowi belum mengumumkan Indonesia dalam keadaan gawat darurat atau garis merah. Presiden hanya mengeluarkan wacana sosial distancing yang bisa dilakukan oleh masyarakat Indonesia, yaitu mulai bekerja di rumah, bersekolah di rumah dan beribadat di rumah (CNN Indonesia, 2020).

Namun penularan Covid 19 ini terus terjadi di Indonesia dengan begitu cepat, keputusan untuk lockdown total atau karantina wilayah pada bulan awal Maret lalu, belum dilakukan oleh pemerintah. Pemerintah masih banyak mempertimbangkan berbagai banyak hal, salah satunya kesiapan untuk hal itu dan ekonomi Indonesia. Pro dan kontra kebijakan dari pemerintah tersebut terus menjadi perdebatan dan pemberitaan di media pemberitaan Indonesia.

Pada tanggal 17 maret 2020, talk show ILC TV ONE mengangkat tema Pro dan Kontra Lockdown. Pada kesempatan itu, narasumber yang dihadirkan yaitu para pejabat negara dan para pakar, diantaranya Gubernur DKI Jakarta, Anies Baswedan dan Gubernur Jawa Barat, Ridwan Kamil, yang pada malam itu kehadiran beliau hanya melalui via video call, karena beliau masih berada di tempat kerja. Selanjutnya yang berada di studio yaitu Ahmad Nur Hidayat (Pakar Kebijakan Publik), Puji Pujiono (Pakar Penanggulangan Bencana), Dani Ambrul Hidat (Tenaga Ahli Utama KSP), Fajur Rahman (Juru Bicara Presiden RI), dokter Erina Burhan (dokter spesialis paru RSUP Persahabatan), dokter Elvira Ibrahim (Pakar Firologi Fakultas Kedokteran UI), Saleh Pataunan (anggota komisi IX DPR RI fraksi PAN), Prof. Effendi Ghazali (Pakar Komunikasi Politik, Rizal Ramli : Ekonom Senior).

Acara talk show ILC TV ONE dikenal dengan pembicaraan atau diskusi yang membahas berbagai isu politik/peristiwa hangat dan terkini yang diulas secara mendalam. Hal ini sejalan dengan pendapat Karni Ilyas sebagaimana dikutip Effendy (2015) ILC adalah sebentuk persuasi untuk melakukan refleksi kritis terhadap berbagai praktik politik dengan penglihatan yang lebih tajam (hlm. 12). Selain itu, tim ILC sering menghadirkan berbagai narasumber termasuk pejabat negara yang kompeten dan relevan terkait topik yang sedang dibahas. ILC juga merupakan termasuk tontonan yang layak diperhitungkan. Hal ini dikarenakan ILC memuat nilai edukatif yang tinggi. ILC pun memiliki rating yang tinggi, banyak minat dari masyarakat dalam menonton acara tersebut.

Setiap narasumber yang diundang di talk show ILC akan disuguhkan satu topik yang sesuai dengan keahlian masing-masing. Untuk satu episode, terdapat banyak narasumber dan juga audiens. Mereka akan berdialog, saling bertukar pendapat dan informasi berdasarkan topik yang telah dipilih. Sosiowati (2013) menyatakan melalui media talk show para narasumber mengemukakan ideologi secara tersurat/tersirat dan mempertahankannya atau 
dengan kata lain mereka melakukan perang ideologi di media tersebut. Ideologi narasumber disampaikan melalui bahasa yang sedemikian rupa agar dapat memengaruhi masyarakatnya.

Sesuai dengan paparan tersebut, analisis tuturan para pejabat negara penting untuk dilakukan. Untuk menganalisis tuturan pejabat negara dilakukan dengan analisis wacana kritis. Pada analisis wacana kritis, bahasa tidak dipandang dalam pengertian linguistik tradisional dan wacana tidak dipahami semata-mata sebagai objek studi bahasa. Seperti pendapat Darma (2009, pp. 49-50); Hastianah (2012); Yudah (2013) dan Riani (2015) bahwa bahasa dalam analisis wacana kritis selain pada teks juga pada konteks bahasa sebagai alat yang dipakai untuk tujuan dan praktik tertentu termasuk praktik ideologi. Dapat dikatakan bahasa dan konteks bahasa bersama-sama digunakan sebagai media melancarkan praktik ideologi tertentu. Analisis wacana kritis melihat wacana (pemakaian bahasa dalam tutur dan tulisan) sebagai bentuk dari praktik sosial (Fairclough, 1997, p. 55; Eriyanto, 2009, p. 7).

Analisis wacana kritis menempatkan masalah representasi menjadi isu utama dalam penelitian kritisnya, karena media menciptakan realitas dengan tata bahasa dan pilihan kosa kata sehingga melahirkan representasi yang beraneka ragam bagi pembaca dan pendengarnya (Ardianto, 2012; Aziz, 2012; Alfianika, 2013; Kuswandari, 2017). Persoalan utama dalam representasi, pada dasarnya adalah penggambaran mengenai seseorang, kelompok, tindakan, atau kegiatan yang tampil di dalam sebuah acara.

Dalam penelitian ini, presentasi di ILC pada tema corona: pro dan kontra lockdown ada misrepresentasi baik dari pihak pejabat sendiri maupun pihak nonpejabat (pakar atau rakyat). Pihak pejabat mungkin membenarkan dan memberikan pengetahuan tentang apa yang dilakukannya atau kebijakan yang diambilnya. Pihak pakar atau rakyat, atau yang lain tidak mengakui, menyudutkan dan menentang apa yang sudah dilakukan oleh pejabat pemerintah. Contoh saja pada diskusi tersebut, saat pejabat pemerintah pada kesempatan ia berbicara; salah satunya Jubir Presiden "semua kebijakan yang diambil Presiden itu sesuai dengan peraturan UU. Karena UU sudah ada mengatur mengenai karantina wilayah". Lalu pihak yang menentang kebijakan yang diambil pemerintah salah satunya datang dari wakil rakyat yaitu Anggota DPR RI Komisi IX yang mengatakan bahwa "pemerintah terlalu lalai mengambil kebijakan".

Penelitian terdahulu mengenai analisis wacana kritis banyak dilakukan, baik itu pada media cetak (koran, majalah, surat kabar), media online, talks show, pidato, berita ditelevisi, bahkan pada karya sastra. Pada media cetak diantaranya dapat dilihat dari penelitian (Setiawan, 2011) tentang pemberitaan kekerasan berbasis gender di Surat Kabar Harian Mardeka, dari penelitiannya ini memberikan jawaban bahwa teks-teks berita tentang kasus kekerasan terhadap wanita yang diproduksi surat kabar tersebut menunjukkan bias gender. Penelitian analisis wacana kritis terhadap acara talk show; seperti yang dilakukan oleh (Lado, 2014) tentang Program Mata Najwa "Balada Perda" di Metro TV, hasil penelitiannya menunjukkan bahwa Mata Najwa membangun wacana bahwa perda melayani kepentingan pemerintah, perda mengintervensi privasi masyarakat, dan perda mendiskriminasi kelompok tertentu. Selanjutnya penelitian analisis wacana kritis terhadap pidato; seperti yang dilakukan (Sumarti, 2010) tentang strategi politik penggunaan bahasa dalam pidato Presiden Susilo Bambang Yudhoyono, hasil penelitiannya menunjukkan bahwa strategi politik penggunaan bahasa dalam pidato Presiden SBY, dalam tataran penggunaan kata, unsur yang tampak adalah penggunaan katakata persona, penggunaan kata yang bernuansa "reformasi", dan "keterbukaan".

Berdasarkan banyak penelitian yang sudah dilakukan mengenai analisis wacana kritis, sesuai dengan fenomena yang terjadi disetiap waktunya tentu penelitian ini mempunyai perbedaan yang jelas dengan penelitian terdahulu. Berdasarkan hal tersebut sesuai dengan problema yang sangat hangat terjadi di negeri ini bahkan dirasakan oleh semua dunia, tetapi 
mempunyai tingkat permasalahan yang berbeda-beda. Oleh karena itu, penelitian ini bertujuan untuk melihat bagaimana representasi pejabat pemerintah tentang pro dan kontra lockdown oleh pihak yang pro dengan kebijakan pejabat pemerintah; dan bagaimana representasi pejabat pemerintah tentang pro dan kontra lockdown oleh pihak yang kontra dengan kebijakan pejabat pemerintah dalam menyampaikan ideologinya dalam tuturan di talk show ILC TV ONE dengan tema Corona: Pro dan Kontra Lockdown, dengan memanfaatkan teori analisis wacana kritis Norman Fairclough untuk mengetahui aspek kebahasaan tuturan pejabat pemerintah dan para pakar dalam merepresentasikan bentuk rasa perlawanan, bentuk praktik wacana, dan aspek kebahasaan yang dihasilkan, serta praktik sosial yang melatarbelakangi aspek kebahasaan yang digunakan.

\section{LANDASAN TEORI}

Analisis wacana kritis Norman Fairclough, pada dasarnya berusaha membangun sebuah model analisis wacana yang mempunyai kontribusi dalam analisis sosial dan budaya. Fairclough dan Wodak (1997, pp. 1-37) menegaskan bahwa analisis wacana kritis melihat wacana (pemakaian bahasa dalam tuturan dan tulisan) sebagai bentuk praktik sosial sehingga bisa jadi menampilkan efek ideologi, memproduksi dan mereproduksi hubungan kekuasaan yang tidak imbang antara kelas sosial, laki-laki, perempuan, maupun kelompok mayoritas dan minoritas. Oleh karena itu, unsur tekstual yang selalu melibatkan bahasa dalam ruang tertutup dikombinasikan dengan konteks masyarakat yang lebih luas. Inti analisis wacana Fairclough adalah melihat bahasa sebagai praktik kekuasaan.

Analisis wacana kritis Fairclough berusaha untuk mengintegrasikan linguistik dengan perubahan sosial sehingga wacana ini disebut sebagai model perubahan sosial (DialecticalRelational Approach/DRA). Fairclough memusatkan perhatian wacana pada bahasa karena pemakaian bahasa digunakan untuk merefleksikan sesuatu. Pertama, wacana adalah bentuk tindakan, bahasa digunakan sebagai bentuk representasi dalam melihat realitas sehingga bahasa bukan hanya diamati secara tradisional atau linguistik mikro, melainkan secara makro yang lebih luas dan tidak lepas dari konteksnya. Kedua, mengimplikasikan adanya hubungan timbal balik antara wacana dan struktur sosial.

Fairclough (dalam Eriyanto, 2001, pp. 286-288) membagi analisis wacana dalam tiga dimensi, yaitu teks, discourse practice, dan socio-cultural practice. (1) Teks digunakan sebagai bentuk representasi sesuatu yang mengandung ideologi tertentu sehingga teks dibongkar secara linguistis karena ingin melihat bagaimana seuatu realitas itu ditampilkan atau dibentuk dalam teks yang bisa jadi membawa pada ideologis tertentu, bagaimana penulis mengonstruksi hubungannya dengan pembaca (baik secara formal atau informal, tertutup atau terbuka), dan bagaimana suatu identitas itu hendak ditampilkan (identitas penulis dan pembaca). Artinya dalam analisis teks ini meliputi representasi, relasi, dan identitas. (2) Discourse practice merupakan dimensi yang berhubungan dengan proses produksi dan konsumsi teks. Proses produksi teks lebih mengarah pada si pembuat teks tersebut. Proses ini melekat dengan pengalaman, pengetahuan, kebiasaan, lingkungan sosial, kondisi, keadaan, konteks, dan sebagainya yang dekat pada diri atau dalam si pembuat teks. Sementara itu, untuk konsumsi teks bergantung pada pengalaman, pengetahuan, konteks sosial yang berbeda dari pembuat teks atau bergantung pada diri pembaca/penikmat bagaimana cara seseorang dapat menerima teks yang telah dihadirkan oleh pembuat teks. Sementara kaitannya dalam distribusi teks, yaitu sebagai modal dan usaha pembuat teks agar hasil karyanya dapat diterima oleh masyarakat. (3) Socio-cultural practice adalah dimensi yang berhubungan dengan konteks diluar teks, seperti konteks situasi. Konteks yang berhubungan dengan masyarakat, atau budaya, dan politik tertentu yang berpengaruh terhadap kehadiran teks. 
Kajian pustaka berkaitan dengan analisis wacana model Norman Fairclough. Mengutip dari (Nugroho, 2012; Siswanto, 2017), analisasis wacana model Norman Fairclough terdiri dari Fairclough menggunakan wacana menunjuk pada pemakaian bahasa sebagai sebuah praktik sosial, lebih daripada aktivitas Individu atau untuk merefleksikan sesuatu. Pertama, wacana adalah bentuk dari tindakan, seseorang menggunakan bahasa sebagai suatu tindakan pada dunia dan khususnya sebagai bentuk representasi dari realita yang ada. Kedua, implikasi adanya hubungan timbal balik antara wacana dan struktur sosial (Eriyanto, 2001).

\section{METODE PENELITIAN}

Penelitian ini menggunakan metode deskriptif kualitatif agar hasil yang telah dicapai benar-benar objektif tanpa dibuat-buat maupun dilebihkan. Selain itu, metode ini dipilih karena diharapkan mampu memberikan analisis dan pendeskripsian secara jelas dan lebih cermat terhadap objek penelitian. Sudaryanto (1993, p. 2) mengatakan istilah deskriptif menyarankan bahwa penelitian yang dilakukan semata-mata hanya berdasarkan pada fakta atau fenomena yang secara empiris hidup pada penutur-penuturnya sehingga data yang dihasilkan berupa bahasa yang sifatnya seperti potret atau paparan. Dalam metode deskriptif kualitatif, penelitian ini dibagi dalam tiga tahapan strategi, meliputi metode pengumpulan data, metode penganalisisan, dan metode penyajian hasil analisis data.

Data didapatkan peneliti dengan melakukan transkrip terlebih dahulu dari rekaman video di youtube dengan bentuk tulisan, agar mudah dalam melakukan penganalisisan tuturan dari pejabat pemerintah. Subyek dalam penelitian ini adalah pejabat pemerintah dan para pakar yang menjadi narasumber dalam acara ILC TV ONE. Sedangkan obyek penelitian ini adalah materi diskusi dan tuturan pejabat pemerintah dalam rekaman video tayangan youtube talkshow Indonesia Lawyers Club TV ONE dengan tema Corona: Pro dan Kontra Lockdown, tayang 17 Maret 2020 (ONE, 2020).

Dalam pengumpulan data ada tiga serangkaian kegiatan ilmiah yang harus dilalui, yakni kurun pencarian masalah, kurun penemuan masalah dan kurun pemecahan masalah. Kurun pemecahan masalah meliputi beberapa tahapan, yakni tahap penyediaan data; yaitu data dikumpulkan dengan melakukan transkrip video, mendengarkan lalu menuliskan semua percakapan, menganalisis data dan penyajian analisis data (Sudaryanto, 1993).

Objek penelitian yang digunakan dibagi menjadi objek material dan objek formal. Objek material penelitian adalah tuturan dari narasumber, yang diambil dari tayangan ILC ataupun dari dokumentasi yang disedia di channel youtube penyelenggara acara. Tuturan-tuturan dalam diskusi pada waktu itu ditranskip dalam bentuk tulisan, dengan melakukan penyimakan dan catat. Sementara itu, objek formalnya adalah analisis wacana kritis Norman Fairclough yang digunakan dalam menjawab dua permasalahan yang telah dijelaskan di latar belakang masalah. Selain itu, untuk menambah wawasan peneliti terhadap hal-hal yang berkaitan dengan objek material, peneliti menggunakan buku-buku literatur, artikel, dan sumber bacaan lain yang dianggap relevan. Penelitian ini melakukan pembacaan/penyimakan dari tuturan dalam diskusi ILC dnegan corona: pro dan kontra lokcdown.

Penelitian ini menggunakan analisis wacana kritis model Norman Fairclough. Analisis wacana N. Fairclough digambarkan mempunyai tiga dimensi atau bangunan, yaitu teks, discourse practice, dan socio-cultural practice. Dimensi pertama, yaitu teks. Teks ini merupakan suatu proses analisis data teks sebagai objek yang diteliti. Dimensi ini melihat bagaimana sesuatu aspek kebahasaan itu ditampilkan melalui representasi, relasi, dan identitas. Dimensi kedua, yaitu discourse practice. Analisis praktik wacana ini dilakukan untuk menentukan bagaimana teks tersebut diproduksi dan dikonsumsi. Dimensi ketiga, yaitu socio-cultural practice. Konteks yang berhubungan dengan masyarakat, atau budaya, dan politik tertentu yang berpengaruh terhadap kehadiran teks. Penelitian ini juga menggunakan studi pustaka dari buku-buku literatur atau sumber bacaan yang relevan dengan masalah tersebut. Setelah dilakukan analisis, selanjutnya 
penyajian hasil analisis data berdasarkan pada penemuan data yang telah dilakukan pada tahapan sebelumnya. Hasil analisis disampaikan secara naratif dan disajikan secara deskriptif agar memudahkan pembaca dalam memahami hasil penelitian. Data yang telah dikumpulkan akan disajikan dalam bentuk uraian kualitatif dan dideskripsikan sesuai dengan teori yang digunakan.

\section{PEMBAHASAN}

Berdasarkan proses pengumpulan data yang telah dilakukan, pada diskusi yang diadakan dalam acara talk show ILC TV ONE ada 6 sesi kesempatan secara bergantian untuk para pejabat pemerintah dan para pakar, bergantian menyampaikan suaranya atas pertanyaan yang diberikan oleh pembawa acara, disini tidak terdapat perdebatan antara narasumber. Narasumber diberi waktu dan kesempatan masing-masingnya untuk menjawab pertanyaan dari pembawa acara dan terkait dengan tema pada malam itu sesuai dengan kondisi yang sedang terjadi. Sesuai yang telah disebutkan sebelum ini, pada bagian pembahasan ini akan dilakukan analisis wacana kritis representasi pada tuturan atau diskusi pejabat pemerintah di acara ILC TV ONE. Untuk menemukan realitas dibalik tuturan pejabat pemerintah yang memengaruhi pandangan masyarakat dan penilian dari kebijakan yang dilakukan pemerintah. Dikarenakan dalam sebuah diskusi tidak lepas akan kepentingan yang bersifat subyektif. Representasi yang akan dilakukan adalah dengan melihat pihak pro dan pihak kontra dari pejabat pemerintah yang menjadi tamu dalam diskusi tersebut. Hasil ditemukan pihak pejabat pemerintah yang menunjukkan pro dan yang kontra dengan kebijakan pemerintah, dapat diperhatikan dalam tabel berikut:

\begin{tabular}{lllll}
\multicolumn{5}{c}{ Tabel 1 Representasi Pejabat } \\
\hline $\begin{array}{l}\text { Representasi pejabat pemerintah tentang } \\
\text { prokontra Lockdown oleh pihak yang pro } \\
\text { dengan kebijakan pejabat pemerintah }\end{array}$ & $\begin{array}{l}\text { Representasi pejabat pemerintah tentang prokontra } \\
\text { Lockdown oleh pihak yang kontra dengan kebijakan } \\
\text { pejabat pemerintah }\end{array}$ \\
\hline Anies Bawesdan (Gubernur DKI Jakarta) & $\begin{array}{l}\text { Anggota komisi IX DPR RI dari fraksi PAN, Saleh } \\
\text { Partaonan Daulay }\end{array}$ \\
\hline Ridwan Kamil (Gubernur Jawa Barat) & Puji Pujiono : Pakar Penanggulangan Bencana & \\
\hline Juru bicara Presiden & Prof. Effendi Ghazali : Pakar Komunikasi Politik & \\
\hline
\end{tabular}

Berdasarkan tabel tersebut, representasi pejabat pemerintah menunjukkan keseimbangan antara pihak yang pro dan pihak yang kontra dengan kebijakan pemerintah. Hal ini menunjukkan jelas bahwa tidak satu suara apakah pro atau kontra lockdown. Tiga dari pejabat pemerintah menunjukkan pro dengan kebijakan yang diambil pemerintah. Tiga lainnya juga menunjukkan kontra dengan kebijakan yang diambil pemerintah.

Makna potensial atas sumber analisis wacana kritis, yang diproduksi dalam peristiwa komunikasi acara ILC TV ONE dengan tema corona: pro dan kontra lockdown. Dengan mendasarkan pada analisis wacana kritis Norman Fairclough berdasarkan tiga dimensi analisis yaitu, teks, diskurus, dan sosial budaya.

\section{Analisis Teks (Mikro)}

Sesuai dengan judul penelitian, pada bagian pembahasan ini akan dilakukan analisis wacana kritis pada diskusi acara ILC dengan tema corona: pro dan kontra lockdown. Untuk menemukan realitas dibalik dibalik tuturan pejabat pemerintah yang memengaruhi pandangan masyarakat dan penilian dari kebijakan yang dilakukan pemerintah. Dikarenakan dalam sebuah diskusi tidak lepas akan kepentingan yang bersifat subyektif. Fairclough membagi analisis wacana teks menjadi tiga elemen dasar untuk menguraikan dan menganalisis 


\section{a. Representasi pejabat pemerintah tentang prokontra Lockdown oleh pihak yang pro dengan kebijakan pejabat pemerintah}

Anies Bawesdan (Gubernur DKI Jakarta)

Kutipan tuturan 1

Jadi ketika ada arah bahwa kita harus melakukan social distencing, maka kita terjemahkan juga dalam bentuk pembatasan menggunakan kendaraan umum. Nah, ini semua sesungguhnya kalo kita berbicara tentang pembatasan mobilitas, kalo tadi berbicaranya lockdown. Lockdown itu bukan satu kasus yang lockdown dan tidak lockdown, ini sebenarnya gradasi, yang kita lakukan sekarang ini adalah kalo berbicara fase, ada 3 fase. Pembatasan kerumunan orang, membatasi gerakan, nol mufmen zero mufmen, limited crout, limited mufmen dan no mufmen atau zero mufmen. Zero mufmen itu yang biasa disebut komplit lockdown. Nah sekarang yang sedang terjadi di Jakarta adalah limited mufmen, membatasi pergerakan dengan cara anjuran bekerja di rumah, fasilitas transfortasi di batasi, kemudian kegiatan-kegiatan umum dikurangi, itu adalah fase kedua. Nah, fase ketiga ini yang biasa disebut sebagai zero lockdown, zero lockdown inilah bukan kewenangan kami, ini adalah kewenangan dari pemerintah pusat, karna kalo ini dilakukan harus ada enfrosmen yang serius tapi kami menganjurkan juga kepada penduduk di Jakarta jangan pulang kampung. Jangan meninggalkan kota, kecuali memang urgent dan pastikan sehat. Karna ada potensi penularan (rekaman video pada sesi: 1 ).

Dari kutipan tuturan Anis Baswedan di atas merupakan repersentasi anak kalimat. Pada aspek ini, pesan menggunakan kosakata dan tata bahasa. Kosakata yang dipakai untuk menampilkan dan menggambarkan sesuatu, yang menunjukkan sesuatu tersebut dimasukkan dalam satu set kategori (Eriyanto, 2009).

Dapat dilihat representasi dalam anak kalimat dari tuturan Anis Baswedan menyampaikan ideologi berupa pendidikan pengetahuan mengenai peristiwa yang terjadi di Jakarta dan yang sedang dilakukan daerah Jakarta berada pada fase kedua yaitu pembatasan gerak atau pembatasan sosial. Anis menjawab pertanyaan dengan tidak lansung kepada inti pertanyaan, ia tetap menjaga pimpinnan yang berada di atasnya atau pemerintah pusat. Bisa dilihat dari cara Anis menjawab penuh dengan pemberian pemahaman untuk kemudian menjawab pertanyaan, hal tersebut dapat diketahui dari pemakainan kosakata-kosatanya menunjukkan pemberian pemahaman dan inti dari jawabannya tidak menunjukkan keputusan langsung. Ia tetap berspekulasi bahwa kebijakan lockdown merupakan kewenangan dari pemerintah pusat.

\section{Kutipan tuturan 2}

Adanya lockdown atau tidaknya itu keputusan pemerintah pusat. Kita menyiapkan factor kesehatannya, factor medisnya, pangan dan lain-lain. Kami berdiskusi rutin dengan teman-teman di bagian prodiksi perdangangan saat ini tantnagannya saat besar, sangat berat. Prosukdi berkurang, tetapi kami memandang ini harus kita kerjakan serius penangannanya, karna nomor satu adalah keselamattan. Karna bila kita bisa membereskan ini, maka insyaallah ini hikmahnya mudah-mudahan kita dapatkan hikmahnya.

Dari kutipan tuturan Anis Baswedan di atas merupakan repersentasi anak kalimat. Pada aspek ini, pesan menggunakan kosakata dan tata bahasa. Kosakata yang dipakai untuk menampilkan dan menggambarkan sesuatu, yang menunjukkan sesuatu tersebut dimasukkan dalam satu set kategori (Eriyanto, 2009).

Dapat dilihat representasi dalam anak kalimat dari tuturan Anis menunjukkan keputusan lockdown kembali kepada tupoksi dari pemerintah pusat. Dari situ dia hanya berspekulasi bahwa ia tetap pada tugasnya untuk menyiapkan segala sesuatu yang dibutuhkan di daerahnya untuk menghadapi situasi baik kesiapan di dalam maupun di luar. Dari representasi tuturan Anis tersebut tidak secara terbuka memberikan keputusan, jika ditanya keinginan hal apa yang harus ditindaklanjuti selanjutnya, sesuai dengan lockdown atau tidak lockdown ia bergeming jika nanti Bapak presiden bertanya, biar saya jawab lansung ke Bapak presiden. Itu artinya ia 
masih menjaga muka pemerintahan dan keputusan yang harus diambil di dalam lingkup pemerintahan itu akan dibicarakan.

\section{Ridwan Kamil (Gubernur Jawa Barat)}

Kutipan tuturan 1

Nah terakhir terkait lockdown ini pendapat kami di daerah, kami setuju bahwa lockdown itu adalah kewenangan pemerintah pusat, karena sifat dari lockdown ini konsekuensinya sangat besar kalo kini supley pangan itu siap, saya kira itu opsi yang dilakukan. Tapi kalo supley logistik dan pangan tidak siap ini akan menimbulkan kekekacauan yang luar biasa, sehingga akhirnya tujuan yang dimaksud tidak terjadi (rekaman video pada sesi 1 ).

Dari kutipan tuturan Ridwan Kamil di atas merupakan repersentasi kombinasi anak kalimat. Pada dasarnya, realitas terbentuk lewat bahasa dengan gabungan antara satu anak kalimat dengan anak kalimat yang lain. Kombinasi atau gabungan dari dua anak kalimat atau lebih dapat membentuk suatu pengertian yang dapat dimaknai dan dapat membentuk koherensi (Eriyanto, 2009).

Dapat dilihat representasi dalam kombinasi anak kalimat dari tuturan Ridwan Kamil tidak menunjukkan keputusan. Ridwan Kamil masih menempatkan dirinya sesuai dengan posisinya, masih ada yang berhak di atasnya untuk mengambil keputusan pro dan kontra lockdown, yaitu pemerintah pusat. Ridwan Kamil hanya menggambarkan pertimbangan dan keadaan atas dilakukan lokdown atau tidak lockdown. Dan dari kalimat yang dituturkan Ridwan Kamil juga sangat lembut, tidak ada keterancaman muka terhadap siapa-siapa, dan ia dalam hal ini juga bersikap musyawarah, terlihat dari kalimat tersebut dia memakai kosakata pendapat kami di daerah.

\section{Kutipan tuturan 2}

Dengan hasil satu positif tadi membuktikan kekhawatiran kami, sehingga pola kewaspadaannya bisa kita lakukan dengan cara yang berbeda-beda. Jadi sekali lagi pemerintah provinsi Jawa Barat akan taat pada protokol pemerintah pusat. Urusan lockdown ini mohon dipertimbangkan banyak positifnya juga dengan syarat kesiapan-kesiapannya terukur dan dampak-dampaknya terukur. Nah, oleh karena itu kami mohon dukungannya di daerah ini banyak yang sedang berjuang untuk memastikan, ini tidak terlalu parah. Terakhir 4 prinsip kami yang kami lakukan, (1) proaktif; (2) transparan; (3) siaga; (4) koordinatif.

Dari kutipan tuturan Ridwan Kamil di atas merupakan repersentasi kombinasi anak kalimat. Pada dasarnya, realitas terbentuk lewat bahasa dengan gabungan antara satu anak kalimat dengan anak kalimat yang lain. Kombinasi atau gabungan dari dua anak kalimat atau lebih dapat membentuk suatu pengertian yang dapat dimaknai dan dapat membentuk koherensi (Eriyanto, 2009).

Dapat dilihat representasi dalam kombinasi anak kalimat dari tuturan Ridwan Kamil menunjukkan menghargai kewenangan pemerintah pusat, tetapi juga menyarankan bahwa urusan lockdown mohon dipertimbangkan juga banyak positifnya asal syarat untuk melakukan lockdown, kesiapan dan dampaknya terukur. Di balik itu Ridwan juga menyampaikan kinerja yang ia lakukan di daerahnya, dengan maksud dapat dilihat dan diketahui.

Koherensi antara anak kalimat di atas merupakan bentuk kedua yaitu perpanjangan.

Juru bicara Presiden

\section{Kutipan Tuturan 1}

Lockdown itu sebenarnya menurut saya, hemat saya itu sebenarnya karantina wilayah. Dan apa yang disebut social distancing. Jadi urutannya gini karantina rumah, karantina RS, karantina wilayah ada juga respon yang lain bang Karni, itu yang disebut sehar-hari terakhir ini social distencing. Padahal di pasal 59 UU No.6 tahun 2018 tentang karantina sudah disebut juga. Namanya pembatasan sosial. Jadi tidak baru, lockdown tidak baru, lockdown itu artinya kekerantinaan wilayah kalo social distancing itu tandanya pembatasan sosial. Saya baca aja, pembatasan sosial berskala besar sebagaimana dimaksud pada ayat 1 sebelumnya, melputi (1) 
peliburan sekolah dan tempat kerja, dilakukan bukan, yang dilakukan sekarang oleh gubernur DKI, gubernur Jawa Barat dan juga oleh Presiden Joko Widodo dengan menghimbau agar bersekolah, bekerja, beribadat juga di rumah. (2) pembatasan keagamaan, juga dilakukan sekarang ini, termasuk terakhir baru hari ini kami menerima dari Majelis Ulama Indonesia, sebelumnya dari PBNU dan lain-lain; (3) adalah pembatasan kegiatan ditempat atau falisitas umum, jadi saya ingin mengatakan bahwa pemerintah sejak UU kekerantinaan kesehatan 7 agustus 2018 sudah sangat siap sesungguhnya menghadapi ini, sudah punya paying hukum. Kemudian masuk ke dalam instruksi Presiden No 4 tahun 2019 dan yang terbaru bang Karni adalah muculnya Kepres No. 7 tahun 2020 yiatu tentang gugus tugas kecepatan penanganan COVID 19, yang ketuanya adalah Kepala Badan Nasional penanggulangan bencana, yaitu LetJed Doni Munardo, seperti itu, jadi pemerintah dalam hal ini ingin mengatakan organisernal lidership, operasional lidership, information lidership itu ada di tangan pemerintah pusat oleh karena situasi kedaduratan ini seperti itu. Bang Karni saya ingin melanjutkan lebih jauh lagi, untuk mencapai tersebut maka pemerintah kemudian juga menciptakan misalnya sejumlah protocol yang diharapkan itu disepakati oleh para pihak seperti itu (rekaman video pada saat sesi: 2).

Dari kutipan tuturan Juru Bicara Presiden di atas merupakan repersentasi anak kalimat. Dapat dilihat representasi dalam anak kalimat dari tuturan Jubir Presiden menunjukkan memberikan pengertian-pengertian dan informasi mengenai UU tentang karantina, untuk menjelaskan keputusan yang diambil oleh presiden yaitu pada tahap karantina rumah atau yang disebut dengan lockdown. Tuturannya menunjukkan representasi melindungi dan memberikan pencerahan mengenai kebijakan yang diambil pemerintah saat itu. Jubir memberikan pengetahuan dan tahap-tahap yang ada di dalam UU, itu yang sedang dilakukan presiden dalam keputusannya belum menginfokan untuk lockdown. Berdasarkan penelitian yang dilakukan oleh Sosiowati (2013, p. 103) representasi anak kalimat adalah aspek ini, pesan menggunakan kosakata dan tata bahasa. Kosakata yang dipakai untuk menampilkan dan menggambarkan sesuatu, yang menunjukkan sesuatu tersebut dimasukkan dalam satu set kategori.

\section{Kutipan Tuturan 2}

Dan bagian terakhir hanya itu saya ingin menambahkan bahwa jadi dalam organisastion lidership ini pemerintah betul-betul mengatakan bahwa kita sudah sangat siap, kita sudah sangat waspada menghadapi yang namanya COVID 19 dengan harapan bahwa tapi pemerintah tidak pernah bisa bekerja sendiri. secara organisasi sudah diatur. Presiden hanya mengumumkan social distancing atau pembatasan sosial, karna pada saat kondisi sekarang ini, cukup dilakukan pembatasan sosial seperti yang dikataka oleh UU, karna tadi satu bang Karni satu yang paling berat yaitu dalam karantina wilayah dimana selama di dalam karantina wilayah kebutuhan hidup dasar orang, kebutuhan hidup dasar orang yang berada di wilayah karantina itu merupakan tangungjawab pemerintah pusat (rekaman pada saat sesi:2).

Selanjutnya representasi dari tuturan sebelumnya, menunjukkan arahan dari keputusan presiden atau dasar ketupusan yang diambil presiden yaitu untuk situasi yang saat ini terjadi pada waktu awal bulan Maret tersebut cukup dilakukan pembatasan sesuai dengan yang dikatakan UU. Tuturan Jubir menunjukkan pencerahan untuk masyarakat dan partipasi diskusi atas kebijakan pemerintah saat itu.

\section{b. Representasi pejabat pemerintah tentang prokontra Lockdown oleh pihak yang kontra dengan kebijakan pejabat pemerintah.}

Anggota komisi IX DPR RI dari fraksi PAN, Saleh Partaonan Daulay

Kutipan Tuturan 1

Sebetulnya kalau ditanya ke saya, saya pengennya ya sudah selesaikan dengan cara lockdown, tegas. Di sinilah kepemimpinan pemerintahan sekarang diuji. Ya bagaimana caranya nanti mengatasi segala macam, ya namanya juga lagi ujian pemerintahnya, silakan dicari solusinya. Apakah kita cukup anggaran dan lain sebagainya. Nanti dicarikan solusi dan formasinya. DPR 
insyaallaah akan bisa bantu, dari sisi tentu pengawasan legiting dan legislasi, kita bisa bantu. Yang kalau sekarang ini belum ada putusan seperti ini, sosial distancing yang ditegaskan, tapi faktanya ini tidak efektif, ya menurut saya kita baing time menunggu waktu saja nanti menyesal, seperti yang katanya orang-orang Italya sekarang menyesal karna mereka terlambat untuk melakukan tindakan-tindakan yang dibutuhkan pada saatnya.

Dari kutipan tuturan Saleh, Anggota Komisi IX DPR RI F PAN di atas merupakan repersentasi rangkaian kalimat. Aspek ini berhubungan dengan bagaimana dua kalimat atau lebih disusun dan dirangkai. Representasi ini berhubungan dengan bagian mana dalam kalimat yang lebih menonjol dibandingkan dengan bagian yang lain (Eriyanto, 2009).

Dapat dilihat representasi dalam rangkaian kalimat dari tuturan Saleh, Anggota Komisi IX DPR RI F PAN menunjukkan bahwa pemerintah lalai dalam mengambil kebijakan dan tidak tegas dalam mengambil keputusan. Ia kontra dengan kebijakan dengan sedang diambil pemerintah pada saat awal Maret yang diumumkan oleh Presiden. Rangkaian kalimat dalam tuturan Saleh tersebut terkesan mengucilkan pemerintah dan menonjolkan dirinya.

\section{Kutipan 2}

Nah, kemudian saya sekarang mulai dari pandangan kritis saya, saya harus menyampaikan ini bukan saya tidak suka dengan pemerintah, saya sudah berkali-kali mengapresiasi kerja pemerintah dalam hal ini, tetapi tentu saya harus menyampaikan karna masyarakat yang saya wakili, juga membutuhkan dan barang kali untuk disampaikan kepada pemerintah. (1) yang ingin saya sampaiakn, tadi terkait sosialisasi kurang masib bang Karni, bahkan nomor telepon pengaduanpun belum tereolisasikan dengan benar, (2) kenapa alat pelindung untuk medis tidak tersedia dengan benar, (3) masker, handnitezer, itu juga hilang. Ternyata menurut BPS temuannya, ini mala mini baru beritanya, bahwa ekspor masker ke Cina Singapur dan Hongkong sejak Januari, Februari menaik 504,5 \% bayangkan sejak kasus ini merebak dari januari-februari belum merebak ke Indonesia tapi negara lain sudah, itu kita ekspor barangnya, ya wajar saja sekarang tidak ada, ya bagaimana caranya memproduksi itu 2 bulan sekarang kita lagi butuh, ini yang slaah siapa bang Karni coba, kenapa bisa seperti itu, ini penting.

Dapat dilihat representasi dalam rangkaian kalimat dari tuturan Saleh, Anggota Komisi IX DPR RI F PAN menunjukkan bahwa ia sebagai pejabat wakil rakyat mengambil muka kepada rakyat dengan mengkritisi pemerintah pusat dan bahkan menyudutkan. Dari tuturannya tersebut mengartikan bahwa ia seperti mempunyai kesempatan beragumen dan membawa hak dan kewajibannya sebagai wakil rakyat.

Puji Pujiono: Pakar Penanggulangan Becana

Kutipan tuturan

Pro atau kontra lockdown. Jawaban saya pro lockdown. Berbeda dengan teman-teman yang lain. Kenapa ada 3 alasan bang Karni. (1) kita tidak tau kapan progesi dari krisis ini akan menuntup lockdown atau karntina wilayah jadi satu keniscayaan. Adakah yang bisa menjadi kalau ini tidak terjadi. (2) kalau kita lihat ke belakang tentang peraturan perundangan bang Karni dari tahun 1700 waktu penjajah belanda kerepotan menghadapi pemberontakan aceh mereka sudah membuat peraturan yang berkaiatn dengan perang dan kedaulatan.

Dari kutipan tuturan Pakar Penanggulan Bencana di atas merupakan repersentasi anak kalimat. Dapat dilihat representasi dalam anak kalimat dari tuturan Pakar Penanggulan Bencana menunjukkan kontra dengan kebijakan yang diambil pemerintah; karena hal yang harus diambil sesuai dengan pengamatannya sebagai ahli, hal yang dilakukan adalah lockdown. Jadi, pemerintah harus menyusun scenario untuk melakukan karantina wilayah; memberikan pengetahuan dan situasi buruk kepada masyarakat tentang wabah ini; yang akan terjadi ke depan seperti apa. Sesuai dengan pandangan Eriyanto (dalam Siswanto, 2017, p. 125). Pada dasarnya, realitas terbentuk lewat bahasa dengan gabungan antara satu anak kalimat dengan anak kalimat yang lain. Kombinasi atau gabungan dari dua anak kalimat atau 
lebih dapat membentuk suatu pengertian yang dapat dimaknai dan dapat membentuk koherensi. Representasi dari tuturan pakar ini menunjukkan sebagai seseorang yang ahli ia hanya memberikan pengetahuan; pendidikan dan gambaran yang harus dilakukan.

Prof. Effendi Ghazali: Pakar Komunikasi Politik

\section{Kutipan tuturan}

Kalau boleh jujur pak jubir memang ini belum maksimal, banyak hal-hal tadi sebut-sebut ya, komunikasi krisis, komunikasi terhadap resiko. Ini masih belum, seperti kadang-kadang yah hal itu terlihat seperti disampaikan secara lancar dan normatif, tapi tidak dianggap transparan dan malah cendrung dianggap bohong, tapi tentu niat tidak jahat. Tapi kemudian karna misliding itu artinya arahnya itu tidak jelas, jadi dianggap seperti tidak transparan dan bohong. Kemudian yang agak penting itu adalah garis bawah kita itu sebetulnya, sama-sama dalam konteks eksuet sanggup, ada seperti pemakluman, saya rasa WHO juga bingung, mau liat WHO bingung, dia tidak bisa segera menempatkan ini sebagai pandemic, harusnya dia agak cepat, mengatakan ini punya potensi sebagai pandemic.

Dari kutipan tuturan Pakar Komunikasi Politik di atas merupakan repersentasi rangkaian kalimat Dapat dilihat reprentasi dalam rangkaian kalimat dari tuturan Pakar Komunikasi Politik menunjukkan bahwa kebijakan yang dilakukan pemerintah; dari tuturannya tersebut menunjukkan pemerintah harus hati-hati dalam setiap keputusan yang diambil dan diminta untuk tansparan dalam memberikan berbagai informasi. Sesuai yang dikatakan Siswanto dalam penelitiannya, aspek dari rangkaian anak kalimat ini berhubungan dengan bagaimana dua kalimat atau lebih disusun dan dirangkai. Representasi ini berhubungan dengan bagian mana dalam kalimat yang lebih menonjol dibandingkan dengan bagian yang lain. Salah satu aspek penting adalah partisipan dianggap mandiri ataukah ditampilkan memberikan reaksi dalam teks berita (Siswanto, 2017, p. 125).

\section{Analisis Praktik Wacana (Meso)}

Teks dibentuk lewat suatu praktik diskursus, yang akan menentukan bagaimana teks tersebut diproduksi (Eriyanto, 2001). Tema "corona: pro dan kontra lockdown" ini dibawakan dalam acara ILC pada tanggal 17 Maret 2020. Tema ini dikemas sesuai dengan kondisi yang sedang dihadapi pemerintah dalam membuat kebijakan atas keadaan khusus yang dihadapi negara dan dunia. Narasumber yang dihadirkan malam itu untuk membahas kebijakan yang harus ditetapkan oleh pemerintah, diantaranya dihadirkan orang-orang seperti: Gubernur DKI Jakarta, Anies Baswedan dan Gubernur Jawa Barat, Ridwan Kamil, yang pada malam itu kehadiran beliau hanya melalui via video call, karena beliau masih berada di tempat kerja. Selanjutnya yang berada di studio yaitu Ahmad Nur Hidayat (Pakar Kebijakan Publik), Puji Pujiono (Pakar Penanggulangan Becana), Dani Ambrul Hidat (Tenaga Ahli Utama KSP), Fajur Rahman (Juru Bicara Presiden RI), dokter Erina Burhan (dokter spesialis paru RSUP Persahabatan), dokter Elvira Ibrahim (Pakar Firologi Fakultas Kedokteran UI), Saleh Pataunan (Anggota Komisi IX DPR RI Fraksi PAN), Prof. Effendi Ghazali (Pakar Komunikasi Politik, Rizal Ramli: Ekonom Senior).

Dengan narasumber yang dihadirkan dalam membahas tema yang disuguhkan. Tentu mempunyai maksud dan tujuan yang positif, sebagai landasan untuk memberikan suguhan edukatif kepada penontonnya. Namun, tidak hanya itu juga menghadirkan pihak yang menentang dan memberikan komentar atas apa yang dijelaskan oleh pihak yang berada dalam pemerintahan.

Berdasarkan uraian di atas dapat diketahui bahwa sebagai seorang yang mempunyai tangung jawab di dalam pemerintahan, pejabat pemerintah dapat memengaruhi sudut pandang dan opini masyarakat untuk bisa memahami dan menyetujui gagasan yang disampaikannya. Begitu dengan para pakar dan Anggota DPR RI akan dapat pulan memengaruhi sudut 
pandang dan opini masyarakat atas kebijakan yang diambil pemerintah belum maksimal dan tidak tegas.

\section{Analisis Praktik Sosial Budaya (Makro)}

Praktik Sosial Budaya menentukan bagaimana teks diproduksi dan dipahami. Praktik sosial budaya menggambarkan kekuatan-kekuatan yang ada dalam masyarakat guna memaknai dan menyebarkan ideologi yang dominan kepada masyarakat. Norman Fairclough membuat tiga level analisis pada Praktik sosial budaya yakni situasional, institusional, dan sosial. Pada sub bagian ini peneliti akan menganalisis faktor kontekstual secara situasional, instituasional dan sosial yang ditemukan pada proses peyampaian opini dan pendapat yang dilakukan narasumber.

Pesan representasi pejabat pemerintah dalam tema corona: pro dan kontra lockdown di acara ILC menciptakan emosional yang positif kepada penonton/masyarakat dari narasumber pihak pemerintah dan emosional yang negatif kepada penonton/masyarakat dari narasumber sebagaian para pakar dan Anggota DPR.

Berdasarkan pembahasan dari hasil temuan data di atas dapat terlihat representasi dari masing-masing pejabat pemerintah yang menjadi narasumber dengan maksud dan tujuan tertentu dari masing-masingnya. Ada 3 temuan representasi dari tuturan pejabat pemerintah atas kebijakan lockdown, yaitu (1) Pejabat pemerintah dalam tuturannya tidak mempunyai kendali yang kuat untuk membuat keputusan, pejabat pemerintah daerah masih bermain aman dan menjaga kehormatan kepada pemerintah diatasnya. (2) Pejabat pemerintah pusat yaitu diwakili oleh jubir Presiden hanya bisa memberikan penjelasan pendidikan mengenai apa itu sosial distancing dan apa itu lockdown; dan (3) Pejabat pemerintah wakil rakyat dan pakar mengkritisi kebijakan yang diambil pemerintah belum maksimal dan tidak tegas. Dari tuturan yang disampaikan wakil rakyat tampak sekali dia memainkan kekuasaannya dengan mengatas dasarkan untuk mewakili suara rakyat, representasi yang sebenarnya dari balik dan kesempatan ia menyampaikan suaranya tersebut adalah mempunyai kesempatan mengkritisi, menyudutkan pemerintah, karena pemerintah sedang dalam menghadapi masalah besar, dan barang tentu segala kebijakan yang diambil pemerintah akan jadi sesuatu yang bisa dikomentari dan mengambil muka kepada rakyat.

Di dalam suatu kesempatan mengkritisi sesuatu hal selalu terdapat maksud dibalik maksud. Dengan kata lain adanya representasi atas suatu kesempatan atau peristiwa yang dilakukan oleh pihak tertentu. Seperti penelitian Wiyatmi (2013) yang membuktikan dalam sebuah karya sastra yang diciptakan pengarang yang sama dalam rentetan karya-karya tulisnya. Mengkritisi suatu peristiwa tidak hanya dapat dilakukan di dalam sebuah forum diskusi tetapi karya sastra merupakan tempat bagi semua orang untuk menyampaikan apa yang ingin di kritiknya. Hasil penelitian terhadap karya sastra novel dari Ayu Utami juga terdapat representasi dari penciptaan novel tersebut. Peristiwa-peristiwa yang dimuat dalam novelnya tersebut direpresentansikan dalam bagian yang integral dengan peristiwa yang dialami oleh tokoh-tokoh dalam novel. Peristiwa sejarah yang berasal dari peristiwa nyata dikontekstualkan dalam novel. Dalam perspektif New Historicism, peristiwa sejarah sosial politik dihadirkan untuk mempertanyakan kembali kebenaran sejarah yang telah dicatat sebelumnya. Sama halnya seperti kritik yang disuarakan oleh wakil rakyat dalam kesempatan diskusi tersebut, pengungkapan pendapat yang dilakukannya dilakukan untuk maksud menyudutkan pemerintah dan menonojolkan dirinya. Sedangkan ketika ia dihadapkan dengan kebijakan di lingkup legislatif, jika dikomentari rakyat, mahasiswa demo, tidak mendengar suara rakyat. Namun dalam keadaan ini, yang sebenarnya merupakan masalah bagi bersama, dia mengataskan dasar mewakili suara rakyat. Dengan terlalu menyudutkan pemerintah. 


\section{PENUTUP}

Setelah melakukan peninjauan ilmiah dari tuturan pejabat pemerintah dalam talkshow ILC TV ONE dengan tema Pro dan Kontra Lockdown dapat ditarik kesimpulan bahwa jelas bahwa tidak satu suara apakah pro atau kontra lockdown, atau diganti namanya, karantina wilayah. Karena banyak pertimbangan dan bayangan-bayangan jika lockdown dilakukan apa dampaknya dan jika tidak dilakukan apapula dampaknya. Pejabat pemerintah dalam tuturannya tidak mempunyai kendali yang kuat untuk membuat keputusan, pejabat pemerintah daerah masih bermain aman dan menjaga kehormatan kepada pemerintah diatasnya. Ada 3 temuan representasi dari tuturan pejabat pemerintah atas kebijakan lockdown, yaitu (1) Pejabat pemerintah dalam tuturannya tidak mempunyai kendali yang kuat untuk membuat keputusan, pejabat pemerintah daerah masih bermain aman dan menjaga kehormatan kepada pemerintah diatasnya. (2) Pejabat pemerintah pusat yaitu diwakili oleh jubir Presiden hanya bisa memberikan penjelasan pendidikan mengenai apa itu sosial distancing dan apa itu lockdown; dan (3) Pejabat pemerintah wakil rakyat dan pakar mengkritisi kebijakan yang diambil pemerintah belum maksimal dan tidak tegas.

\section{DAFTAR PUSTAKA}

Alfianika, N. (2013). Analisis Wacana Kritis Teori Inclusion Theo Van Leeuwen dalam Berita Kriminal Tema Pencurian Koran Posmetro Padang Edisi Mei 2013. GRAMATIKA STKIP PGRI Sumatera Barat, 2 (1). https://doi.org/10.22202/jg.2016.v2i1.1407

Ardianto. (2012). Analisis Wacana Kritis Pemberitaan Harian Pikiran Rakyat Dan Harian Kompas Sebagai Public Relations Politik Dalam Membentuk Branding Reputation Presiden Susilo Bambang Yudhoyono (SBY). Ilmu Komunikasi, 2 (1). www.neliti.com

Aziz, A. (2012). Penggunaan Kosakata dalam Wacana Politik sebagai Representasi Ideologi. RETORIKA: Jurnal Bahasa, Sastra Dan Pengajarannya, 8, No 1. http://doi.org/10.26858/retorika.v8i1.517

CNN Indonesia. (2020). Cerita Virus Corona Sejauh Ini. Laman Berita Online CNN Indonesia.

Darma, Y. A. (2009). Analisis Wacana Kritis. CV Yrama Widya.

Effendy, O. U. (2015). Ilmu Komunikasi Teori dan Praktek. PT. Remaja Rosdakarya.

Eriyanto. (2001). Analisis Wacana: Pengantar Analisis Teks Media. LKIS Group.

Eriyanto. (2009). Analisis Wacana: Pengantar Teks Media. LKIS Group.

Fairclough, N. dan R. W. (1997). Critical Discourse Analysis" dalam Teun Van Dijk. Discourse as Social Interaction. Sage.

Hastianah, N. (2012). Analisis Wacana dalam Sinrilik Kappalak Tallumbatua. SAWERIGADING, 18, No 1. https://doi.org/10.26499/sawer.v18i1.363

Kuswandari, A. H. (2017). Analisis Wacana: Representasi Pendidikan Indonesia pada Berita Online Detik.com. Jurnal Metalingua, 15 No 2. https://doi.org/10.26499/metalingua.v15i2.120

Lado, C. R. (2014). Analisis Wacana Kritis Program Mata Najwa "Balada Perda" di Metro TV. EKomunikasi, 2 (2) hlm . http://jurnal.upyk.ac.id

Nugroho, A. S. (2012). Analisis Wacana Kritis terhadap Iklan-Iklan Pajak dalam Pembentukan Realitas pada Kehidupan Masyarakat. RANAH Kajian Bahasa, 1, (1). https://doi.org/10.26499/rnh.v1i1.18

ONE, T. (2020). Indonesia Lawyers Club. Channel Youtube ILC TV ONE.

Riani. (2015). Kajian Wacana Iklan pada Pesan Singkat (SMS). RANAH Kajian Bahasa, 4, No 1. https://doi.org/10.26499/rnh.v4i1.24

Setiawan, Y. B. (2011). Analisis Wacana Kritis Pemberitaan Kekerasan Berbasis Gender di Surat Kabar Harian Suara Mardeka. Ilmiah Komunikasi MAKNA, 2 (1).

Siswanto, A. (2017). Representasi Indonesia dalam Stand Up Comedy Pertunjukan Pandji Pragiwaksono "Mesakke Bangsaku." KANAL (Jurna Ilmu Komunikasi, 5 (2). https://doi.org/10.21070/kanal.v5i2.1508

Sosiowati, G. G. (2013). Kesantunan Bahasa Politisi dalam Talk Show di Metro TV. Universitas Udayana. 
Sudaryanto. (1993). Metode dan Aneka Teknik Analisis Bahasa. Duta Wacana University Press.

Sumarti, E. (2010). Analisis Wacana Kritis Strategi Politik Penggunaan Bahasa dalam Pidato Presiden Susilo Bambang Yudhoyono. LITERA, 9 (1), https://doi.org/10.21831//tr.v9i1.1215

Wiyatmi. (2013). Representasi Sejarah Indonesia Dalam Novel Novel Karya Ayu Utami. Litera, 12 (2), https://doi.org/10.21831/ltr.v12i02.1545

Yudah, A. A. P. (2013). Representasi Transgender dan Transeksual dalam Pemberitaan di Media Massa: Sebuah Tinjauan Analisis Wacana Kritis. Kriminologi Indonesia, 9 (1), Des. 